\title{
Pengaruh pemberian amelioran dolomit dengan pupuk kandang ayam terhadap tanaman pakcoy yang tumbuh di lahan gambut
}

\author{
The efferct of dolomite ameliorant application with chicken manure to pakcoy plants grown in \\ peatlands \\ Paska Aprianto ${ }^{1, *}$, Salampak ${ }^{2}$, Susi Kresnatita ${ }^{2}$ \\ ${ }^{1}$ Dinas Sosial Kabupaten Gunung Mas \\ 2 Program Studi Magister Pengelolaan Sumberdaya Alam dan Lingkungan Program Pascasarjana Universitas Palangka Raya \\ * Korespondensi: Paska Aprianto (Email: apriantopaska@gmail.com)
}

https://e-journal.upr.ac.id/index.php/jem

https://doi.org/10.37304/jem.v2i2.2941

\begin{abstract}
This study aims to determine the effect of ameliorant on the productivity of Pakcoy plants in peat soil. This research used a non-factorial completely randomized design (CRD) with 7 levels of treatment repeated 5 times. The research treatment without ameliorant as a control $\left(G_{0} P_{0}\right), 10 t h^{-1}$ chicken manure $\left(G_{0} P_{1}\right), 20 t$ ha $a^{-1}$ chicken manure $\left(G_{0} P_{2}\right), 30 t h a^{-1}$ chicken manure $\left(G_{0} P_{3}\right)$, dolomite $4 t h a^{-1}+$ chicken manure $10 t h a^{-1}\left(G_{1} P_{1}\right)$, dolomite 4 t ha $a^{-1}+$ chicken manure 20 t ha ${ }^{1}\left(G_{1} P_{2}\right)$ and $4 t h a^{-1}+$ chicken manure $30 t h a^{-1}\left(G_{1} P_{3}\right)$. The research was conducted at UPT CIMTROP of the University of Palangka Raya in Jekan Raya District, Palangka Raya City from July to August 2020. The variables observed included plant height, leaf area, stover dry weight, and dry weight of Pakcoy roots. The results showed that from all growth parameters of Pakcoy plants, the combination dose of dolomite $4 t h a^{-1}+$ chicken manure $30 t_{h a^{-1}}$ affected the increase in the highest average productivity of all treatments.
\end{abstract}

\section{Keywords}

Amelioration, dolomite, chicken manure, pakcoy, peatland

\section{Intisari}

Penelitian ini bertujuan untuk mengetahui pengaruh bahan amelioran terhadap produktivitas tanaman pakcoy di tanah gambut. Metode penelitian ini menggunakan Rancangan Acak Lengkap (RAL) non faktorial dengan 7 taraf perlakuan, diulang sebanyak 5 kali. Perlakuan tanpa amelioran sebagai kontrol $\left(\mathrm{G}_{0} \mathrm{P}_{0}\right)$, Pupuk Kandang Ayam 10 t ha ${ }^{-1}$ $\left(\mathrm{G}_{0} \mathrm{P}_{1}\right)$, Pupuk Kandang Ayam $20 \mathrm{t} \mathrm{ha}^{-1}\left(\mathrm{G}_{0} \mathrm{P}_{2}\right)$, Pupuk Kandang Ayam $30 \mathrm{t} \mathrm{ha}^{-1}\left(\mathrm{G}_{0} \mathrm{P}_{3}\right)$, Dolomit $4 \mathrm{t} \mathrm{ha}{ }^{-1}+$ Pupuk Kandang Ayam $10 \mathrm{t} \mathrm{ha}^{-1}\left(\mathrm{G}_{1} \mathrm{P}_{1}\right)$, Dolomit $4 \mathrm{t} \mathrm{ha}^{-1}$ + Pupuk Kandang Ayam $20 \mathrm{t} \mathrm{ha}^{-1}\left(\mathrm{G}_{1} \mathrm{P}_{2}\right)$ dan Dolomit $4 \mathrm{t} \mathrm{ha}{ }^{-1}+$ Pupuk Kandang Ayam $30 \mathrm{t} \mathrm{ha}^{-1}\left(\mathrm{G}_{1} \mathrm{P}_{3}\right)$. Penelitian dilaksanakan di UPT CIMTROP Universitas Palangka Raya, Kecamatan Jekan Raya, Kota Palangka Raya pada bulan Juli hingga Agustus 2020. Variabel yang diamati meliputi tinggi tanaman, luas daun, berat kering brangkasan dan berat kering akar tanaman pakcoy. Hasil penelitian menunjukkan dari semua

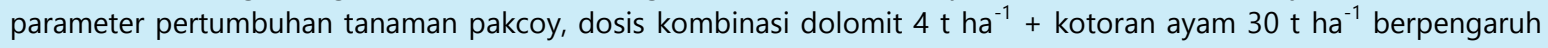
terhadap peningkatan produktivitas rata-rata tertinggi dari semua perlakuan.

Kata kunci

Amelioran, dolomit, pupuk kandang ayam, pakcoy, tanah gambut

\section{PENDAHULUAN}

Pakcoy (Brassica rapa L.) adalah tanaman sayuran daun yang satu genus dengan sawi. Pakcoy merupakan tanaman yang berumur pendek memiliki kandungan gizi. Pakcoy merupakan salah satu tanaman yang memiliki nilai ekonomis tinggi, untuk itu perlu adanya peningkatan produksi pakcoy (Wahyuningsih et al., 2017).
Budidaya tanaman pakcoy di Kalimantan tengah pada masih terbatas dalam skala kecil. Produksi tanaman pakcoy di Kalimantan Tengah tahun pada tahun 2016 sebesar 14 ton, pada tahun 2017 sebesar 17 ton dan pada tahun 2018 sebesar 14 ton (BPS, 2018).

Masalah utama yang menyebabkan budidaya tanaman pakcoy kurang berkembang adalah lahan pertanian yang didominasi oleh tanah gambut. Lahan gambut di Indonesia 
pada umumnya bereaksi masam, memiliki tingkat kesuburan yang rendah, dan miskin unsur hara. Unsur hara mikro lahan gambut umumnya terdapat dalam jumlah yang sangat rendah, sehingga menyebabkan gejala defisiensi bagi tanaman. Manurung (2017) menyatakan bahwa lahan gambut mempunyai beberapa faktor pembatas seperti rendahnya ketersediaan unsur hara tanah, hal ini karena pada lahan gambut dengan $\mathrm{pH}$ rendah dan bahan organik tinggi sebagian besar unsur hara berada dalam komplek jerapan dengan bahan organik (khelat). Kondisi ini dapat diatasi dengan penggunaan bahan amelioran karena dapat menurunkan kemasaman tanah, seiring dengan peningkatan nilai $\mathrm{pH}$ tanah akan meningkatkan kejenuhan basa dan kesuburan tanah. Lubis et al. (2017) meyatakan bahwa amelioran adalah bahan yang dapat meningkatkan kesuburan tanah melalui perbaikan kondisi fisik dan kimia. Kriteria amelioran yang baik bagi lahan gambut adalah memiliki kejenuhan basa (KB) yang tinggi, mampu meningkatkan derajat $\mathrm{pH}$ secara nyata, mampu memperbaiki struktur tanah, memiliki kandungan unsur hara yang lengkap, dan mampu mengusir senyawa beracun terutama asam-asam organik. Bahan amelioran yang digunakan biasanya meliputi bahan organik sisa tanaman, sisa hewan, biochar dan dolomit.

Penelitian bertujuan untuk mengetahui pengaruh amelioran berbagai dosis pupuk kandang ayam dan dosis kombinasi amelioran dolomit dengan pupuk kandang ayam terhadap produktivitas tanaman pakcoy di tanah gambut.

\section{METODOLOGI}

\subsection{Bahan dan Alat}

Bahan-bahan yang digunakan dalam penelitian ini adalah tanah gambut (hemik) dari Kelurahan Kalampangan, Kecamatan Sebangau, Kota Palangka Raya. Benih pakcoy Nauli F1 (Cap Panah Merah), Dolomit (MgO: 18-22\%, Ca O: $\pm 30 \%$ sedangkan bahan baku berupa phosphor gypsum dan karbon dioksida $\left(\mathrm{CO}_{2}\right)$, pupuk kandang ayam ras dengan kandungan ( $\mathrm{N}$-tot 1,20\%, P-tot 1508,08 ppm dan $\mathrm{K}$ -tot 12553,15 ppm), NPK Mahkota 16-16-16, kayu bulat, balok $5 \times 5$ dan papan.

Alat yang digunakan dalam penelitian ini adalah polybag ukuran $8 \times 9 \mathrm{~cm}$, polybag ukuran $35 \times 40 \mathrm{~cm}$, paranet $50 \%$, label penelitian, gembor, kertas milimeter, pengaris, alat tulis, kawat ayakan ukuran $5 \mathrm{~mm}$, terpal ukuran $4 \times 6 \mathrm{~m}$, penggaris, timbangan tahita, timbangan idealife, kalkulator dan oven.

\subsection{Rancangan Penelitian}

Metode penelitian ini menggunakan Rancangan Acak Lengkap (RAL) non faktorial dengan 7 taraf perlakuan, di ulang sebanyak 5 kali. Perlakuan tanpa amelioran sebagai kontrol $\left(G_{0} P_{0}\right)$, Pupuk Kandang Ayam $10 \mathrm{t} \mathrm{ha}^{-1}\left(\mathrm{G}_{0} \mathrm{P}_{1}\right)$, Pupuk Kandang Ayam $20 \mathrm{t} \mathrm{ha}^{-1}\left(\mathrm{G}_{0} \mathrm{P}_{2}\right)$, Pupuk Kandang
Ayam $30 \mathrm{t} \mathrm{ha}^{-1}\left(\mathrm{G}_{0} \mathrm{P}_{3}\right)$, Dolomit $4 \mathrm{t} \mathrm{ha}^{-1}+$ Pupuk Kandang Ayam $10 \mathrm{t} \mathrm{ha}^{-1}\left(\mathrm{G}_{1} \mathrm{P}_{1}\right)$, Dolomit $4 \mathrm{t} \mathrm{ha}^{-1}+$ Pupuk Kandang Ayam $20 \mathrm{t} \mathrm{ha}^{-1}\left(\mathrm{G}_{1} \mathrm{P}_{2}\right)$ dan Dolomit $4 \mathrm{t} \mathrm{ha}^{-1}+$ Pupuk Kandang Ayam $30 \mathrm{t} \mathrm{ha}^{-1}\left(\mathrm{G}_{1} \mathrm{P}_{3}\right)$. Penelitian dilaksanakan di UPT CIMTROP Universitas Palangka Raya, Kecamatan Jekan Raya, Kota Palangka Raya pada bulan Juli hingga Agustus 2020. Variabel yang diamati meliputi tinggi tanaman, luas daun, berat kering brangkasan dan berat kering akar tanaman pakcoy.

\subsection{Penarikan Sampel}

Metode penarikan sampel yang digunakan adalah simple random sampling, yaitu cara pengambilan sampel dari anggota populasi dengan menggunakan acak tanpa memperhatikan strata (tingkatan) dalam anggota populasi tersebut. Setiap satuan percobaan terdiri dari 7 perlakuan dan di ulang sebanyak 5 kali sehingga tanaman sampel yang diamati dalam penelitian ini sebanyak 35 tanaman. Pengamatan yang dilakukan meliputi tinggi tanaman, luas daun yang dilakukan setiap 2 minggu sekali dan pengamatan berat kering brangkasan dan berat kering akar pada saat panen.

\subsection{Prosedur Penelitian}

\section{- Persiapan Kebun Penelitian}

Persiapan awal yang dilakukan sebelum penelitian adalah membersihkan lokasi penelitian dari gulma. Membuat rak kayu 5 buah dan diatur dengan posisi berjarak tiap rak $70 \mathrm{~cm}$, ketinggian rak dari permukaan tanah yaitu $50 \mathrm{~cm}$, dan panjang rak $5 \mathrm{~m}$ dengan atap naungan dari bahan paranet $50 \%$ untuk mengurangi paparan cahaya matahari.

\section{- Persiapan Media Tanam dan Pemberian Label Perlakuan}

Media tanam yang digunakan adalah polybag ukuran $35 \times 40 \mathrm{~cm}$, setelah itu tanah gambut dijemur selama 1 minggu supaya kering lalu diayak dan di isi ke polybag. Setiap polybag diisi tanah gambut dengan berat $5 \mathrm{~kg} /$ polybag. Polybag disusun pada rak yang terbuat dari kayu lalu diberi kode perlakuan. Tiap rak diletakkan 7 buah polybag dengan penempatan yang telah diacak.

\section{- Persemaian}

Benih pakcoy disemaikan dengan media tanah gambut menggunakan polybag ukuran $8 \times 9 \mathrm{~cm}$, persemaian dilakukan selama 14 hari hingga pertumbuhan daun sekitar 4 helai.

\section{- Pemberian Perlakuan}

Bahan amelioran yang digunakan ditimbang sesuai dengan perencanaan, pemberian perlakuan dilakukan setelah polybag diisi dengan tanah gambut yang telah diayak seberat $5 \mathrm{~kg} /$ polybag. Pemberian perlakuan disesuaikan dengan label perlakuan yang telah terpasang sebelumnya dengan cara diaduk merata dengan media tanah gambut pada semua polybag. Label perlakuan menunjukkan jenis dan dosis amelioran tiap perlakuan. 


\section{- Penanaman}

Bibit pakcoy yang telah berumur 14 hari dan sudah memiliki 4 helai daun kemudian dipindahkan ke polybag besar dengan media tanah gambut.

\section{- Pemeliharaan}

Pemeliharaan yang dilakukan meliputi penyiraman, pemberantasan gulma, pengendalian organisme pengganggu tumbuhan (OPT). Pemupukan pakcoy menggunakan pupuk NPK mahkota 16:16:16 dengan dosis $200 \mathrm{~kg} \mathrm{ha}^{-1}\left(2,3 \mathrm{~g}\right.$ polybag $\left.{ }^{-1}\right)$. Waktu pemupukan hanya dilakukan saat tanaman umur 10 hari setelah tanam.

\section{- Panen}

Pakcoy dipanen setelah tanaman berumur 56 hari mulai dari penyemaian.

\subsection{Analisis Data}

Analisis data menggunakan program SPSS 21, dalam analisis data yang bersifat parametrik syarat dari normalitas dan homogenitas data harus terpenuhi agar menghasilkan kesimpulan yang valid. Sebelum melakukan anlisis data maka dilakukan uji normalitas dan uji homogenitas, setelah lolos kedua uji tersebut maka dilanjutkan dengan uji anova dan uji ortogonal kontras.

Makna perbandingan perlakuan yang disusun dengan 6 koefisien:

Ket: Kombinasi amelioran (dolomit + pupuk kandang)

$C_{1}$ : tanpa perlakuan (kontrol) vs semua perlakuan

$C_{2}$ : pupuk kandang ayam vs kombinasi amelioran

C3 : pukan. a10 tha-1 pukan. a 20 dan $30 \mathrm{t} \mathrm{ha}^{-1}$

C4 : pukan. a 20 vs pukan. a $30 \mathrm{t} \mathrm{ha}^{-1}$

C5 : kombinasi amelioran $10 \mathrm{t} \mathrm{ha}^{-1}$ vs kombinasi amelioran
20 dan 30 t ha $^{-1}$

C6 : kombinasi amelioran $20 \mathrm{t} \mathrm{ha}^{-1}$ vs kombinasi amelioran 30 t ha $^{-1}$

\section{HASIL}

\subsection{Tinggi Tanaman}

Hasil analisis sidik ragam menunjukan berbeda nyata terhadap tinggi tanaman pada umur 14, 28 dan 42 hari setelah tanam (hst) (Tabel 2).

Tabel 2. Tabel rata-rata tinggi tanaman akibat perlakuan amelioran

\begin{tabular}{ccccc}
\hline \multirow{2}{*}{ Perlakuan } & \multicolumn{4}{c}{ Rata-rata tinggi tanaman (cm) } \\
\cline { 2 - 5 } & $\mathbf{1 4}$ (hst) & $\mathbf{2 8}$ (hst) & $\mathbf{4 2}$ (hst) & $\begin{array}{c}\text { Rata- } \\
\text { rata }\end{array}$ \\
\hline $\mathrm{G}_{0} \mathrm{P}_{0}$ & 10.1 & 15.6 & 18.7 & 13.7 \\
$\mathrm{G}_{0} \mathrm{P}_{1}$ & 10.2 & 16.2 & 20.2 & 14.3 \\
$\mathrm{G}_{0} \mathrm{P}_{2}$ & 11.0 & 18.4 & 23.3 & 15.9 \\
$\mathrm{G}_{0} \mathrm{P}_{3}$ & 11.4 & 18.8 & 23.5 & 16.6 \\
$\mathrm{G}_{1} \mathrm{P}_{1}$ & 11.6 & 19.5 & 24.3 & 17.1 \\
$\mathrm{G}_{1} \mathrm{P}_{2}$ & 12.1 & 19.6 & 24.7 & 17.5 \\
$\mathrm{G}_{1} \mathrm{P}_{3}$ & 12.0 & 20.9 & 25.9 & 18.1 \\
\hline $\mathrm{Ujji}_{\mathrm{F}} \mathrm{s}$ & $\mathrm{s}$ & $\mathrm{s}$ & $\mathrm{s}$ & $\mathrm{s}$ \\
\hline
\end{tabular}

Keterangan: ns: non signifikan, s: signifikan

Karena hasil analisis sidik ragam menunjukkan hasil beda nyata pada semua perlakuan, maka akan dilanjutkan dengan uji ortognal kontras pada tabel Tabel 3 .

Tabel 1 Susunan koefisien ortogonal kontras

\begin{tabular}{|c|c|c|c|c|c|c|c|c|}
\hline \multirow{2}{*}{$\frac{\text { Koefisien }}{C_{1}}$} & \multirow{2}{*}{$\begin{array}{c}\text { Perbandingan Perlakuan } \\
G_{0} P_{0} \text { vs }\left(G_{0} P_{1}, G 0 P_{2}, G_{0} P_{3}, G_{1} P_{1}, G_{1} P_{2}, G_{1} P_{3}\right)\end{array}$} & \multicolumn{7}{|c|}{ Susunan Koefisien } \\
\hline & & 6 & -1 & -1 & -1 & -1 & -1 & -1 \\
\hline $\mathrm{C}_{2}$ & $\left(G_{0} P_{1}, G_{0} P_{2}, G_{0} P_{3}\right)$ vs $\left(G_{1} P_{1}, G_{1} P_{2}, G_{1} P_{3}\right)$ & 0 & 1 & 1 & 1 & -1 & -1 & -1 \\
\hline $\mathrm{C}_{3}$ & $\mathrm{G}_{0} \mathrm{P}_{1}$ vs $\left(\mathrm{G}_{0} \mathrm{P}_{2}, \mathrm{G}_{0} \mathrm{P}_{3}\right)$ & 0 & 2 & -1 & -1 & 0 & 0 & 0 \\
\hline $\mathrm{C}_{4}$ & $\mathrm{G}_{0} \mathrm{P}_{2}$ vs $\mathrm{G}_{0} \mathrm{P}_{3}$ & 0 & 0 & 1 & -1 & 0 & 0 & 0 \\
\hline $\mathrm{C}_{5}$ & $G_{1} P_{1}$ vs $\left(G_{1} P_{2}, G_{1} P_{3}\right)$ & 0 & 0 & 0 & 0 & 2 & -1 & -1 \\
\hline $\mathrm{C}_{6}$ & $G_{1} P_{2}$ vs $G_{1} P_{3}$ & 0 & 0 & 0 & 0 & 0 & 1 & -1 \\
\hline
\end{tabular}

Tabel 3. Uji ortogonal kontras terhadap tinggi tanaman pakcoy $(\mathrm{cm})$

\begin{tabular}{clccc} 
Koefisien & \multicolumn{1}{c}{ Perbandingan Perlakuan } & Ket & Perlakuan & Rata-Rata \\
\hline$C_{1}$ & $\mathrm{G}_{0} \mathrm{P}_{0}$ vs $\left(\mathrm{G}_{0} \mathrm{P}_{1}, \mathrm{G}_{0} \mathrm{P}_{2}, \mathrm{G}_{0} \mathrm{P}_{3}, \mathrm{G}_{1} \mathrm{P}_{1}, \mathrm{G}_{1} \mathrm{P}_{2}, \mathrm{G}_{1} \mathrm{P}_{3}\right)$ & $* *$ & $\mathrm{G}_{0} \mathrm{P}_{0}$ & $13.7 \mathrm{a}$ \\
$\mathrm{C}_{2}$ & $\left(\mathrm{G}_{0} \mathrm{P}_{1}, \mathrm{G}_{0} \mathrm{P}_{2}, \mathrm{G}_{0} \mathrm{P}_{3}\right)$ vs $\left(\mathrm{G}_{1} \mathrm{P}_{1}, \mathrm{G}_{1} \mathrm{P}_{2}, \mathrm{G}_{1} \mathrm{P}_{3}\right)$ & $* *$ & $\mathrm{G}_{0} \mathrm{P}_{1}$ & $14.3 \mathrm{~b}$ \\
$\mathrm{C}_{3}$ & $\mathrm{G}_{0} \mathrm{P}_{1}$ vs $\left(\mathrm{G}_{0} \mathrm{P}_{2}, \mathrm{G}_{0} \mathrm{P}_{3}\right)$ & $* *$ & $\mathrm{G}_{0} \mathrm{P}_{2}$ & $15.9 \mathrm{c}$ \\
$\mathrm{C}_{4}$ & $\mathrm{G}_{0} \mathrm{P}_{2}$ vs $\mathrm{G}_{0} \mathrm{P}_{3}$ & $\mathrm{~ns}$ & $\mathrm{G}_{0} \mathrm{P}_{3}$ & $16.6 \mathrm{c}$ \\
$\mathrm{C}_{5}$ & $\mathrm{G}_{1} \mathrm{P}_{1}$ vs $\left(\mathrm{G}_{1} \mathrm{P}_{2}, \mathrm{G}_{1} \mathrm{P}_{3}\right)$ & $*$ & $\mathrm{G}_{1} \mathrm{P}_{1}$ & $17.1 \mathrm{e}$ \\
$\mathrm{C}_{6}$ & $\mathrm{G}_{1} \mathrm{P}_{2}$ vs $\mathrm{G}_{1} \mathrm{P}_{3}$ & $\mathrm{~ns}$ & $\mathrm{G}_{1} \mathrm{P}_{2}$ & $17.5 \mathrm{f}$ \\
\hline
\end{tabular}

Ket: Angka yang diikuti dengan huruf yang sama pada kolom rata-rata berbeda tidak nyata pada uji Ortogonal Kontras taraf $5 \%$. dan tanda ** berbeda sangat nyata, * berbeda nyata, ns: non signifikan. 
Tabel 2 memperlihatkan perbedaan perbandingan tinggi tanaman yang diberikan perlakuan amelioran sebagai berikut:

$\checkmark \mathrm{C}_{1}$ : Tanaman yang diberi perlakuan bahan amelioran lebih tinggi dan berbeda sangat nyata dibanding dengan yang tidak diberi perlakuan bahan amelioran.

$\checkmark \mathrm{C}_{2}$ :Tanaman dengan perlakuan berbagai dosis pupuk kandang ayam menghasilkan tanaman yang lebih pendek dan berbeda sangat nyata dibanding dengan perlakuan berbagai dosis kombinasi bahan amelioran.

$\checkmark C_{3}$ : Tanaman dengan perlakuan amelioran pupuk kandang ayam 10 ton ha- 1 lebih rendah dan berbeda sangat nyata dibanding dengan yang dosis amelioran pupuk kandang 20 ton-1 dan dosis amelioran pupuk kandang 30 ton ha- 1.

$\checkmark \mathrm{C}_{4}$ : Tanaman yang diberi perlakuan amelioran pupuk kandang ayam 20 ton-1 lebih pendek dan tidak berbeda nyata dibanding dengan dosis amelioran pupuk kandang 30 ton ha- 1 .

$\checkmark C_{5}$ : Tanaman yang diberi perlakuan kombinasi amelioran dolomit 4 ton ha- 1 + pupuk kandang ayam 10 ton-1 lebih pendek dan berbeda nyata dibanding dengan kombinasi amelioran dolomit 4 ton ha- $1+$ pupuk kandang ayam 20 ton-1 dan kombinasi ameliorant dolomit 4 ton ha-1 + pupuk kandang ayam 30 ton-1.

$\checkmark$ C $_{6}$ : Tanaman yang di perlakuan kombinasi amelioran dolomit 4 ton ha- 1 + pupuk kandang ayam 20 ton-1 memperlihatkan tanaman lebih pendek dan tidak berbeda nyata dibanding dengan kombinasi amelioran dolomit 4 ton ha- 1 + pupuk kandang ayam 30 ton $^{-1}$.

Untuk mengetahui laju pertumbuhan tanaman dilakukan pengukuran tinggi tanaman setiap 2 minggu sekali dimulai dari umur 14 hst sampai tanaman berumur 42 hst. Laju pertumbuhan tinggi tanaman pakcoy yang dipengaruhi oleh berbagai dosis dan jenis amelioran serta kombinasinya disajikan pada Gambar 1.

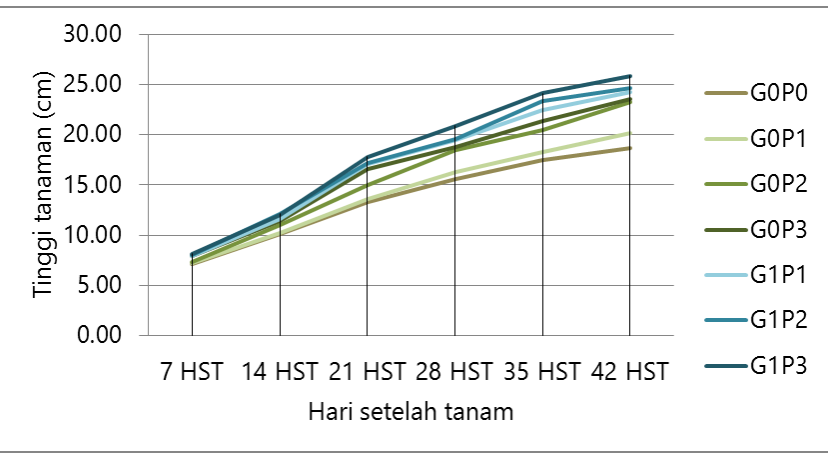

Gambar 1 Pengaruh berbagai dosis dan jenis amelioran serta kombinasinya terhadap pertumbuhan tinggi tanaman pakcoy di tanah gambut

Pada Gambar 1 terlihat bahwa semua perlakuan $\mathrm{G}_{0} \mathrm{P}_{0}$, $G_{0} P_{1}, G_{0} P_{2}, G_{0} P_{3}, G_{1} P_{1}, G_{1} P_{2}$ dan $G_{1} P_{3}$ menunjukkan laju pertumbuhan tinggi yang hampir sama. Pertumbuhan tinggi tanaman pada pengamatan minggu ke-2 menunjukkan laju pertumbuhan yang mulai meningkat dan mulai menunjukkan perbedaan antar perlakuan. Pengamatan tinggi tanaman pada minggu ke-4 dan minggu ke-6 menunjukkan laju pertumbuhan yang semakin meningkat dan terjadi perbedaan yang nyata dan sangat nyata pada semua perlakuan $\left(G_{0} P_{0}, G_{0} P_{1}, G_{0} P_{2}, G_{0} P_{3}\right.$ $G_{1} P_{1}, G_{1} P_{2}$ dan $G_{1} P_{3}$ )

\subsection{Luas Daun}

Hasil analisis sidik ragam menunjukkan berbeda tidak nyata terhadap luas daun tanaman pada umur 7 hst dan berbeda sangat nyata pada umur 14, 28, dan 42 hst (Tabel 4).

Tabel 4. Tabel rata-rata luas daun $\left(\mathrm{cm}^{2}\right)$ akibat perlakuan amelioran

\begin{tabular}{ccccc}
\hline \multirow{2}{*}{ Perlakuan } & \multicolumn{4}{c}{ Rata-rata luas daun $\mathbf{( c m}^{\mathbf{2}}$ ) } \\
\cline { 2 - 5 } & $\mathbf{1 4}$ (hst) & $\mathbf{2 8}$ (hst) & $\mathbf{4 2}$ (hst) & $\begin{array}{c}\text { Rata- } \\
\text { rata }\end{array}$ \\
\hline $\mathrm{G}_{0} \mathrm{P}_{0}$ & 5.83 & 26.35 & 39.87 & 20.72 \\
$\mathrm{G}_{0} \mathrm{P}_{1}$ & 6.74 & 30.15 & 40.35 & 22.22 \\
$\mathrm{G}_{0} \mathrm{P}_{2}$ & 6.91 & 36.31 & 60.02 & 28.64 \\
$\mathrm{G}_{0} \mathrm{P}_{3}$ & 8.38 & 37.57 & 62.81 & 30.62 \\
$\mathrm{G}_{1} \mathrm{P}_{1}$ & 8.65 & 46.81 & 73.50 & 35.57 \\
$\mathrm{G}_{1} \mathrm{P}_{2}$ & 8.89 & 47.65 & 74.73 & 36.07 \\
$\mathrm{G}_{1} \mathrm{P}_{3}$ & 9.00 & 47.73 & 83.85 & 38.63 \\
\hline $\mathrm{Uji}_{\mathrm{i}} \mathrm{F}$ & $\mathrm{s}$ & $\mathrm{s}$ & $\mathrm{s}$ & $\mathrm{s}$
\end{tabular}

Keterangan: ns: non signifikan, s: signifikan

Karena hasil analisis sidik ragam menunjukkan hasil beda nyata pada semua perlakuan, maka akan dilanjutkan dengan uji ortognal kontras pada Tabel 5.

Tabel 5 memperlihatkan perbedaan perbandingan luas daun yang diberikan perlakuan amelioran sebagai berikut:

$\checkmark \quad C_{1}$ : Tanaman yang diberi bahan amelioran memiliki luas daun yang lebih besar dan berbeda sangat nyata dibanding dengan yang tidak diberi perlakuan bahan amelioran.

$\checkmark \mathrm{C}_{2}$ :Tanaman dengan perlakuan berbagai dosis pupuk kandang ayam menghasilkan luas daun yang lebih rendah dan berbeda sangat nyata dibanding dengan perlakuan berbagai kombinasi bahan amelioran.

$\checkmark C_{3}$ : Tanaman dengan perlakuan amelioran pupuk kandang ayam 10 ton ha $^{-1}$ memiliki luas daun lebih rendah berbeda sangat nyata dibanding dengan yang dosis amelioran pupuk kandang 20 ton $^{-1}$ dan dosis amelioran pupuk kandang 30 ton $\mathrm{ha}^{-1}$.

$\checkmark \quad C_{4}$ : Tanaman yang diberi perlakuan amelioran pupuk kandang ayam 20 ton $^{-1}$ memiliki luas daun yang lebih rendah dan berbeda sangat nyata dibanding dengan dosis amelioran pupuk kandang 30 ton ha ${ }^{-1}$.

$\checkmark C_{5}$ : Tanaman yang diberi perlakuan kombinasi amelioran dolomit 4 ton ha- 1 + pupuk kandang ayam 10 ton $^{-1}$ I memiliki luas daun yang lebih rendah dan berbeda sangat nyata dibanding dengan kombinasi 
Tabel 5. Tabel uji ortogonal kontras luas daun $\left(\mathrm{cm}^{2}\right)$

\begin{tabular}{cllll}
\hline Koefisien & \multicolumn{1}{c}{ Perbandingan Perlakuan } & Ket & Perlakuan & Rata-Rata \\
\hline $\mathrm{C}_{1}$ & $\mathrm{G}_{0} \mathrm{P}_{0}$ vs $\left(\mathrm{G}_{0} \mathrm{P}_{1}, \mathrm{G}_{0} \mathrm{P}_{2}, \mathrm{G}_{0} \mathrm{P}_{3}, \mathrm{G}_{1} \mathrm{P}_{1}, \mathrm{G}_{1} \mathrm{P}_{2}, \mathrm{G}_{1} \mathrm{P}_{3}\right)$ & $* *$ & $\mathrm{G}_{0} \mathrm{P}_{0}$ & $20.71 \mathrm{a}$ \\
$\mathrm{C}_{2}$ & $\left(\mathrm{G}_{0} \mathrm{P}_{1}, \mathrm{G}_{0} \mathrm{P}_{2}, \mathrm{G}_{0} \mathrm{P}_{3}\right)$ vs $\left(\mathrm{G}_{1} \mathrm{P}_{1}, \mathrm{G}_{1} \mathrm{P}_{2}, \mathrm{G}_{1} \mathrm{P}_{3}\right)$ & $* *$ & $\mathrm{G}_{0} \mathrm{P}_{1}$ & $22.22 \mathrm{~b}$ \\
$\mathrm{C}_{3}$ & $\mathrm{G}_{0} \mathrm{P}_{1}$ vs $\left(\mathrm{G}_{0} \mathrm{P}_{2}, \mathrm{G}_{0} \mathrm{P}_{3}\right)$ & $* *$ & $\mathrm{G}_{0} \mathrm{P}_{2}$ & $28.63 \mathrm{c}$ \\
$\mathrm{C}_{4}$ & $\mathrm{G}_{0} \mathrm{P}_{2}$ vs $\mathrm{G}_{0} \mathrm{P}_{3}$ & $* *$ & $\mathrm{G}_{0} \mathrm{P}_{3}$ & $30.61 \mathrm{~d}$ \\
$\mathrm{C}_{5}$ & $\mathrm{G}_{1} \mathrm{P}_{1}$ vs $\left(\mathrm{G}_{1} \mathrm{P}_{2}, \mathrm{G}_{1} \mathrm{P}_{3}\right)$ & $* *$ & $\mathrm{G}_{1} \mathrm{P}_{1}$ & $35.57 \mathrm{e}$ \\
$\mathrm{C}_{6}$ & $\mathrm{G}_{1} \mathrm{P}_{2}$ vs $\mathrm{G}_{1} \mathrm{P}_{3}$ & $* *$ & $\mathrm{G}_{1} \mathrm{P}_{2}$ & $36.06 \mathrm{f}$ \\
\hline & & & $\mathrm{G}_{1} \mathrm{P}_{3}$ & $38.62 \mathrm{~g}$
\end{tabular}

Ket: Angka yang diikuti dengan huruf yang sama pada kolom rata-rata berbeda tidak nyata pada uji Ortogonal Kontras taraf $5 \%$. dan tanda $* \star$ berbeda sangat nyata, * berbeda nyata, ns: non signifikan.

amelioran dolomit 4 ton ha- 1 + pupuk kandang ayam 20 ton $^{-1}$ dan kombinasi amelioran dolomit 4 ton ha-1 + pupuk kandang ayam 30 ton $^{-1}$.

$\checkmark \quad C_{6}$ : Tanaman yang di perlakuan kombinasi amelioran dolomit 4 ton ha-1 + pupuk kandang ayam 20 ton $^{-1}$ memperlihatkan luas daun lebih rendah dan sangat berbeda nyata dibanding dengan kombinasi amelioran dolomit 4 ton ha-1 + pupuk kandang ayam 30 ton $^{-1}$.

Untuk mengetahui pertumbuhan luas daun dilakukan pengukuran luas daun setiap 2 minggu sekali dimulai dari umur 14 hst setelah penanaman sampai umur 42 hst. Adapun pertumbuhan luas daun tanaman pakcoy yang dipengaruhi oleh berbagai dosis dan jenis amelioran serta kombinasinya disajikan pada Gambar 2.

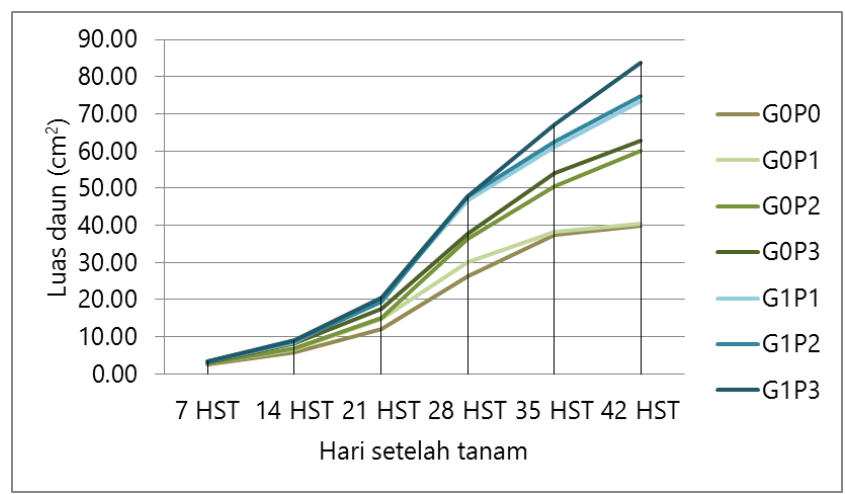

Gambar 2 Pengaruh berbagai dosis dan jenis amelioran serta kombinasinya terhadap pertumbuhan luas daun tanaman pakcoy $\left(\mathrm{cm}^{2}\right)$ di tanah gambut

Pada Gambar 2 terlihat bahwa semua perlakuan $\mathrm{G}_{0} \mathrm{P}_{0}$, $G_{0} P_{1}, G_{0} P_{2}, G_{0} P_{3}, G_{1} P_{1}, G_{1} P_{2}$ dan $G_{1} P_{3}$ menunjukkan laju pertumbuhan luas daun yang hampir sama pada minggu ke-2 setelah tanam. Kemudian pada minggu ke-4 dan ke- 6 terjadi perbedaan yang sangat nyata terhadap penambahan luas daun pada semua perlakuan baik $G_{0} P_{0}$, $G_{0} P_{1}, G_{0} P_{2}, G_{0} P_{3}, G_{1} P_{1}, G_{1} P_{2}$ dan $G_{1} P_{3}$.

\subsection{Berat Kering Brangkasan Tanaman}

Hasil analisis sidik ragam menunjukan berbeda nyata terhadap berat kering brangkasan tanaman (Tabel 6).

Tabel 6 Tabel rata-rata berat kering brangkasan tanaman (g) akibat perlakuan amelioran

\begin{tabular}{cc}
\hline Perlakuan & Rata-rata Berat kering (g) \\
\hline $\mathrm{G}_{0} \mathrm{P}_{0}$ & 1.88 \\
$\mathrm{G}_{0} \mathrm{P}_{1}$ & 2.80 \\
$\mathrm{G}_{0} \mathrm{P}_{2}$ & 3.86 \\
$\mathrm{G}_{0} \mathrm{P}_{3}$ & 4.84 \\
$\mathrm{G}_{1} \mathrm{P}_{1}$ & 5.84 \\
$\mathrm{G}_{1} \mathrm{P}_{2}$ & 6.88 \\
$\mathrm{G}_{1} \mathrm{P}_{3}$ & 7.76 \\
\hline $\mathrm{Uji} \mathrm{F}$ & $\mathrm{s}$ \\
\hline
\end{tabular}

Keterangan: ns: non signifikan, s: signifikan

Karena hasil analisis sidik ragam menunjukkan hasil berbeda nyata pada semua perlakuan, maka akan dilanjutkan dengan uji ortognal kontras (Tabel 7).

Tabel 7 memperlihatkan perbedaan perbandingan berat kering brangkasan yang diberikan perlakuan amelioran sebagai berikut:

$\checkmark \quad C_{1}$ : Tanaman yang diberi bahan amelioran memiliki berat kering brangkasan yang lebih besar dan berbeda sangat nyata dibanding dengan yang tidak diberi perlakuan bahan amelioran.

$\checkmark \quad \mathrm{C}_{2}$ :Tanaman dengan perlakuan berbagai dosis pupuk kandang ayam menghasilkan berat kering brangkasan yang lebih rendah dan berbeda sangat nyata dibanding dengan perlakuan berbagai kombinasi bahan amelioran.

$\checkmark \mathrm{C}_{3}$ :Tanaman dengan perlakuan amelioran pupuk 
Tabel 7 Uji ortogonal kontras berat kering brangkasan tanaman (g)

\begin{tabular}{|c|c|c|c|c|}
\hline Koefisien & Perbandingan Perlakuan & Ket & Perlakuan & Rata-Rata \\
\hline $\mathrm{C}_{1}$ & $G_{0} P_{0}$ vs $\left(G_{0} P_{1}, G_{0} P_{2}, G_{0} P_{3}, G_{1} P_{1}, G_{1} P_{2}, G_{1} P_{3}\right)$ & ** & $\mathrm{G}_{0} \mathrm{P}_{0}$ & $1.88 \mathrm{a}$ \\
\hline $\mathrm{C}_{2}$ & $\left(G_{0} P_{1}, G_{0} P_{2}, G_{0} P_{3}\right)$ vs $\left(G_{1} P_{1}, G_{1} P_{2}, G_{1} P_{3}\right)$ & ** & $\mathrm{G}_{0} \mathrm{P}_{1}$ & $2.80 \mathrm{~b}$ \\
\hline $\mathrm{C}_{3}$ & $\mathrm{G}_{0} \mathrm{P}_{1}$ vs $\left(\mathrm{G}_{0} \mathrm{P}_{2}, \mathrm{G}_{0} \mathrm{P}_{3}\right)$ & ** & $\mathrm{G}_{0} \mathrm{P}_{2}$ & $3.86 c$ \\
\hline $\mathrm{C}_{4}$ & $G_{0} P_{2}$ vs $G_{0} P_{3}$ & ** & $\mathrm{G}_{0} \mathrm{P}_{3}$ & $4.84 d$ \\
\hline $\mathrm{C}_{5}$ & $G_{1} P_{1}$ vs $\left(G_{1} P_{2}, G_{1} P_{3}\right)$ & ** & $\mathrm{G}_{1} \mathrm{P}_{1}$ & $5.84 \mathrm{e}$ \\
\hline \multirow[t]{2}{*}{$\mathrm{C}_{6}$} & $G_{1} P_{2}$ vs $G_{1} P_{3}$ & ** & $G_{1} P_{2}$ & $6.88 f$ \\
\hline & & & $\mathrm{G}_{1} \mathrm{P}_{3}$ & $7.76 \mathrm{~g}$ \\
\hline
\end{tabular}

Ket: Angka yang diikuti dengan huruf yang sama pada kolom rata-rata berbeda tidak nyata pada uji Ortogonal Kontras taraf $5 \%$. dan tanda ** berbeda sangat nyata, * berbeda nyata, ns: non signifikan.

kandang ayam 10 ton ha $^{-1}$ memiliki berat kering brangkasan lebih rendah berbeda sangat nyata dibanding dengan yang dosis amelioran pupuk kandang 20 ton $^{-1}$ dan dosis amelioran pupuk kandang 30 ton ha $^{-1}$.

$\checkmark \mathrm{C}_{4}$ : Tanaman yang diberi perlakuan amelioran pupuk kandang ayam 20 ton $^{-1}$ memiliki berat kering brangkasan yang lebih rendah dan berbeda sangat nyata dibanding dengan dosis amelioran pupuk kandang 30 ton $\mathrm{ha}^{-1}$.

$\checkmark C_{5}$ : Tanaman yang diberi perlakuan kombinasi ameliorant dolomit 4 ton ha- 1 + pupuk kandang ayam 10 ton $^{-1}$ I memiliki berat kering brangkasan yang lebih rendah dan berbeda sangat nyata dibanding dengan kombinasi ameliorant dolomit 4 ton ha- 1 + pupuk kandang ayam 20 ton $^{-1}$ dan kombinasi ameliorant dolomit 4 ton ha-1 + pupuk kandang ayam 30 ton $^{-1}$.

$\checkmark C_{6}$ : Tanaman yang diberi perlakuan kombinasi ameliorant dolomit 4 ton ha- 1 + pupuk kandang ayam 20 ton $^{-1}$ memperlihatkan berat kering brangkasan lebih rendah dan berbeda sangat nyata dibanding dengan kombinasi ameliorant dolomit 4 ton ha- $1+$ pupuk kandang ayam 30 ton $^{-1}$.

Untuk mengetahui berat kering brangkasan tanaman maka dilakukan penimbangan setelah tanaman dikeringkan di dalam oven dengan suhu $130^{\circ} \mathrm{C}$ selama 24 jam. Adapun berat kering brangkasan tanaman pakcoy yang dipengaruhi oleh berbagai dosis dan jenis amelioran serta kombinasinya dapat dilihat pada Gambar 3.

Pada Gambar 3 terlihat bahwa semua perlakuan baik $G_{0} P_{0}, G_{0} P_{1}, G_{0} P_{2}, G_{0} P_{3}, G_{1} P_{1}, G_{1} P_{2}$ dan $G_{1} P_{3}$ menunjukkan berat kering brangkasan tanaman yang berbeda nyata. Pada perlakuan $\mathrm{G}_{0} \mathrm{P}_{0}$ memiliki berat kering brangkasan terendah sebesar $1,88 \mathrm{~g}$ dan berbeda sangat nyata dengan perlakuan $G_{0} P_{1}, G_{0} P_{2}, G_{0} P_{3}, G_{1} P_{1}, G_{1} P_{2}$ dan $G_{1} P_{3}$ yang memiliki berat kering brangkasan tertinggi dengan berat
$7,76 \mathrm{~g}$.

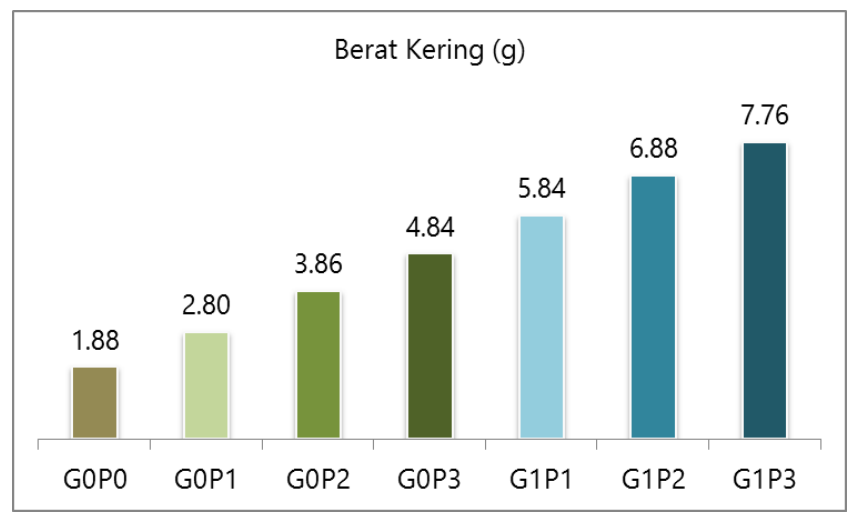

Gambar 3 Pengaruh berbagai macam dan dosis amelioran serta kombinasinya terhadap berat kering brangkasan tanaman pakcoy (g) di tanah gambut

\subsection{Berat Kering Akar Tanaman}

Hasil analisis sidik ragam menunjukan berbeda nyata terhadap berat kering akar tanaman (Tabel 8).

Tabel 8 Rata-rata berat kering akar tanaman (g) akibat perlakuan amelioran

\begin{tabular}{cc}
\hline Perlakuan & Rata-rata Berat Kering Akar (g) \\
\hline $\mathrm{G}_{0} \mathrm{P}_{0}$ & 0.42 \\
$\mathrm{G}_{0} \mathrm{P}_{1}$ & 1.38 \\
$\mathrm{G}_{0} \mathrm{P}_{2}$ & 2.26 \\
$\mathrm{G}_{0} \mathrm{P}_{3}$ & 2.98 \\
$\mathrm{G}_{1} \mathrm{P}_{1}$ & 3.22 \\
$\mathrm{G}_{1} \mathrm{P}_{2}$ & 3.78 \\
$\mathrm{G}_{1} \mathrm{P}_{3}$ & 4.30 \\
\hline $\mathrm{Uji}_{\mathrm{ji}}$ & $\mathrm{s}$ \\
\hline
\end{tabular}

Keterangan: ns: non signifikan, s: signifikan 
Tabel 9 Uji ortogonal kontras berat kering akar tanaman

\begin{tabular}{|c|c|c|c|c|}
\hline Koefisien & Perbandingan Perlakuan & Ket & Perlakuan & Rata-Rata \\
\hline $\mathrm{C}_{1}$ & $G_{0} P_{0}$ vs $\left(G_{0} P_{1}, G_{0} P_{2}, G_{0} P_{3}, G_{1} P_{1}, G_{1} P_{2}, G_{1} P_{3}\right)$ & ** & $\mathrm{G}_{0} \mathrm{P}_{0}$ & $0.42 \mathrm{a}$ \\
\hline $\mathrm{C}_{2}$ & $\left(G_{0} P_{1}, G_{0} P_{2}, G_{0} P_{3}\right)$ vs $\left(G_{1} P_{1}, G_{1} P_{2}, G_{1} P_{3}\right)$ & ** & $\mathrm{G}_{0} \mathrm{P}_{1}$ & $1.38 b$ \\
\hline $\mathrm{C}_{3}$ & $\mathrm{G}_{0} \mathrm{P}_{1}$ vs $\left(\mathrm{G}_{0} \mathrm{P}_{2}, \mathrm{G}_{0} \mathrm{P}_{3}\right)$ & ** & $\mathrm{G}_{0} \mathrm{P}_{2}$ & $2.26 c$ \\
\hline $\mathrm{C}_{4}$ & $\mathrm{G}_{0} \mathrm{P}_{2}$ vs $\mathrm{G}_{0} \mathrm{P}_{3}$ & ** & $\mathrm{G}_{0} \mathrm{P}_{3}$ & $2.98 d$ \\
\hline$C_{5}$ & $G_{1} P_{1}$ vs $\left(G_{1} P_{2}, G_{1} P_{3}\right)$ & ** & $\mathrm{G}_{1} \mathrm{P}_{1}$ & $3.22 \mathrm{e}$ \\
\hline \multirow[t]{2}{*}{$\mathrm{C}_{6}$} & $G_{1} P_{2}$ vs $G_{1} P_{3}$ & ** & $G_{1} P_{2}$ & $3.78 f$ \\
\hline & & & $\mathrm{G}_{1} \mathrm{P}_{3}$ & $4.3 \mathrm{~g}$ \\
\hline
\end{tabular}

Ket: Angka yang diikuti dengan huruf yang sama pada kolom rata-rata berbeda tidak nyata pada uji Ortogonal Kontras taraf $5 \%$. dan tanda ** berbeda sangat nyata, * berbeda nyata, ns: non signifikan.

Karena hasil analisis sidik ragam menunjukkan hasil berbeda nyata pada semua perlakuan, maka akan dilanjutkan dengan uji ortognal kontras pada Tabel 9.

Tabel 9 memperlihatkan perbedaan perbandingan berat kering akar tanaman yang diberikan perlakuan amelioran sebagai berikut:

$\checkmark \quad C_{1}$ : Tanaman yang diberi bahan amelioran memiliki berat kering akar yang lebih besar dan berbeda sangat nyata dibanding dengan yang tidak diberi perlakuan bahan amelioran.

$\checkmark \quad C_{2}$ :Tanaman dengan perlakuan berbagai dosis pupuk kandang ayam menghasilkan berat kering akar yang lebih rendah dan berbeda sangat nyata dibanding dengan perlakuan berbagai kombinasi bahan amelioran.

$\checkmark C_{3}$ : Tanaman dengan perlakuan amelioran pupuk kandang ayam 10 ton ha ${ }^{-1}$ memiliki berat kering akar lebih rendah dan berbeda sangat nyata dibanding dengan yang dosis amelioran pupuk kandang 20 ton $^{-1}$ dan dosis amelioran pupuk kandang 30 ton ha ${ }^{-1}$.

$\checkmark C_{4}$ : Tanaman yang diberi perlakuan amelioran pupuk kandang ayam 20 ton $^{-1}$ memiliki berat kering akar yang lebih rendah dan berbeda sangat nyata dibanding dengan dosis amelioran pupuk kandang 30 ton ha-1.

$\checkmark C_{5}$ : Tanaman yang diberi perlakuan kombinasi ameliorant dolomit 4 ton ha- 1 + pupuk kandang ayam 10 ton $^{-1}$ I memiliki berat kering akar yang lebih rendah dan berbeda sangat nyata dibanding dengan kombinasi ameliorant dolomit 4 ton ha- 1 + pupuk kandang ayam 20 ton $^{-1}$ dan kombinasi ameliorant dolomit 4 ton ha- $1+$ pupuk kandang ayam 30 ton $^{-1}$.

$\checkmark$ C $_{6}$ : Tanaman yang diberi perlakuan kombinasi ameliorant dolomit 4 ton ha- 1 + pupuk kandang ayam 20 ton $^{-1}$ memperlihatkan berat kering akar lebih rendah berbeda sangat nyata dibanding dengan kombinasi ameliorant dolomit 4 ton ha- 1 + pupuk kandang ayam 30 ton $^{-1}$.

Untuk mengetahui berat kering akar tanaman maka dilakukan penimbangan setelah tanaman dikeringkan di dalam oven dengan suhu $130^{\circ} \mathrm{C}$ selama 24 jam. Berat kering akar tanaman pakcoy yang dipengaruhi oleh berbagai dosis dan jenis amelioran serta kombinasinya disajikan pada Gambar 4.

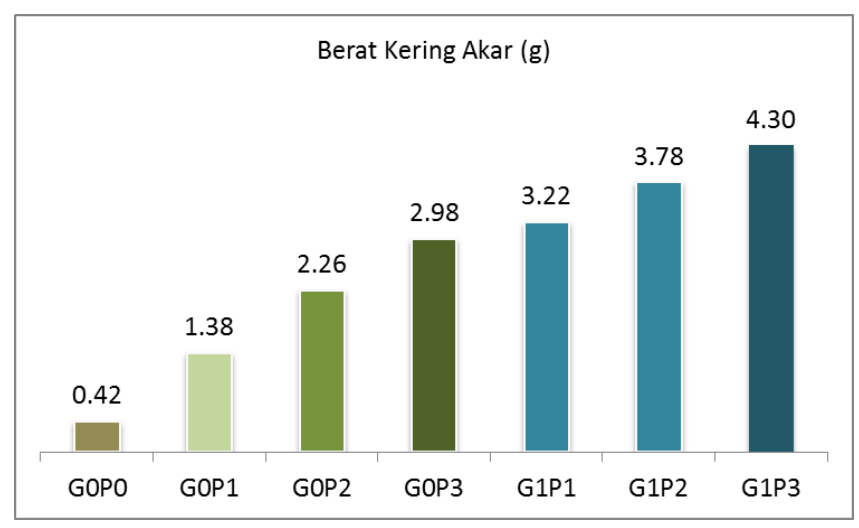

Gambar 4 Pengaruh berbagai dosis dan jenis amelioran serta kombinasinya terhadap berat kering akar tanaman pakcoy (g) di tanah gambut

Pada Gambar 4 terlihat bahwa semua perlakuan $\mathrm{G}_{0} \mathrm{P}_{0}$, $G_{0} P_{1}, G_{0} P_{2}, G_{0} P_{3}, G_{1} P_{1}, G_{1} P_{2}$ dan $G_{1} P_{3}$ menunjukkan berat kering akar tanaman yang berbeda nyata pada semua perlakuan. Perlakuan $\mathrm{G}_{0} \mathrm{P}_{0}$ memiliki berat kering akar terendah sebesar $0,42 \mathrm{~g}$ dan berbeda sangat nyata dengan perlakuan $G_{0} P_{1}, G_{0} P_{2}, G_{0} P_{3}, G_{1} P_{1}, G_{1} P_{2}$ dan $G_{1} P_{3}$, sedangkan berat kering akar tertinggi yaitu $4,30 \mathrm{~g}$ terdapat pada perlakuan $G_{1} P_{3}$. 


\section{PEMBAHASAN}

Perlakuan pupuk organik kandang ayam terbukti mampu memperbaiki struktur tanah, meningkatkan kemampuan tanah dalam menyerap air dan meningkatkan ketersediaan hara sehingga mampu meningkatkan pertumbuhan tanaman. Ditambah lagi dengan dolomit yang berperan menetralkan $\mathrm{pH}$ tanah sehingga ketersediaan unsur hara didalam tanah gambut menjadi mudah diserap oleh tanaman. Hal ini senada dengan pendapat Sari et al. (2019) mengatakan bahwa bahan amelioran seperti pupuk organik, tanah mineral, zeolit, dolomit, fosfat alam, pupuk kandang, kapur pertanian, abu sekam dan purun tikus dapat meningkatkan $\mathrm{pH}$ tanah dan basa-basa tanah yang menunjang pertumbuhan tanaman.

Peningkatan $\mathrm{pH}$ tanah gambut terjadi akibat penambahan bahan amelioran pupuk kandang ayam yang digunakan, hal ini senada Aryanti et al (.2017) dimana pupuk kandang ayam memiliki $\mathrm{pH}$ yang netral serta memiliki pupuk kotoran ayam memiliki $\mathrm{pH}$ netral dikarenakan bahan organik banyak mengandung senyawa organik sederhana dalam bentuk gugus karboksil dan phenolik yang mampu mengikat Al dan Fe membuka ikatan kompleks, sehingga $\mathrm{Al}$ dan Fe tidak mampu menyumbang kanion $\mathrm{H}^{+}$kedalam tanah yang berarti kondisi ini menurunkan kemasaman.

Sedangkan dolomit juga berpengaruh dalam meningkatkan $\mathrm{pH}$ tanah, hal ini senada dengan Aryanti et al. (2017) yang menyatakan bahwa dolomit mengandung unsur $\mathrm{Ca}$ dan $\mathrm{Mg}$, dimana kedua unsur ini menggeser kedudukan $\mathrm{H}+$ dipermukaan koloid, sehingga menetralisir keasaman tanah. Selain melalui reaksi hidrolisis dapat melepaskan ion $\mathrm{OH}^{-}$yang berpengaruh terhadap peningkatan $\mathrm{pH}$ tanah (Lubis dan Hidayat, 2019).

Amelioran dengan dosis yang tinggi menghasilkan pengaruh terbaik pada semua parameter pertumbuhan dan hasil tanaman. Hal ini menunjukkan bahwa pemberian dosis amelioran.memberikan kontribusi terhadap pertumbuhan dan hasil tanaman pakcoy. Pupuk kandang yang kaya akan unsur hara makro dan mikro sangat menunjang laju pertumbuhan tanaman terutama organ vegatif tanaman. Hal ini senada dengan Rahman et al. (2020) yang mengatakan bahwa pupuk kandang mengandung unsur hara makro dan mikro sehingga meningkatkan ketersediaan unsur hara dan meningkatkan efesiensi penyerapan unsur hara oleh akar dibanding dengan bahan organik yang lain pupuk kandang ayam memiliki kandungan $\mathrm{N}$ cukup tinggi.

Pemberian amelioran yang hanya berasal dari pupuk kandang ayam memberikan hasil yang lebih rendah dibandingkan dengan perlakuan kombinasi dolomit dengan tambahan pupuk kandang ayam.karena unsur hara yang berasal dari pupuk kandang ayam lambat untuk dilepaskan. Hal ini senada dengan Kusuma (2016), bahwa pupuk kandang kotoran ayam merupakan sumber unsur hara dengan adanya dekomposisi bahan organik oleh mikroorganisme tanah yang berlangsung secara lamban sehingga unsur hara akan tersedia secara perlahan-lahan (slow release) akan tetapi terus menerus sehingga ketersediaannya dapat digunakan tanaman pada periode tanam selanjutnya.

Pemberian kapur dolomit dan pupuk kandang ayam pada tanah gambut selain dapat menaikkan $\mathrm{pH}$ tanah juga dapat meningkatkan ketersediaan unsur hara makro dan mikro bagi tanaman, sehingga dapat meningkatkan pertumbuhan dan hasil tanaman yang terbaik pada semua perlakuan. Hal ini senada dengan Nurhayati (2020) mengatakan bahwa peningkatan pertumbuhan vegetatif tanaman yang diberi kapur karena adanya perbaikan penyediaan hara bagi tanaman.

Peningkatan pertumbuhan dan hasil tanaman memiliki kaitan yang erat dengan serapan unsur $N, P$, dan $K$. Semakin tinggi serapan $N, P$ dan $K$ semakin baik pertumbuhan tanaman. Hal ini senada dengan pendapat Atmajadan Damanik (2017) mengatakan bahwa unsur hara makro N, P dan K merupakan unsur hara yang esensial bagi tanaman, yang sangat berperan dalam proses pertumbuhan tanaman, yaitu meliputi proses fotosintesis, respirasi, transfer dan penyimpanan energi, pembelahan dan pembesaran sel serta proses-proses yang lainya

Sedangkan pada perlakuan kontrol tanpa pemberian amelioran (dolomit dan pupuk kandang ayam) menunjukan pertumbuhan terendah terhadap tinggi tanaman dan mengalami gejala kahat unsur hara. Hal ini disebabkan faktor media tanam tanah gambut yang memiliki $\mathrm{pH}$ tanah sangat masam. Hal ini salah satu masalah yang dihadapi tanaman yang tumbuh di tanah masam akibat kurang tersedianya unsur hara sehingga tanaman tumbuh kerdil. Nazari (2020) mengatakan bahwa defisiensi unsur hara $P$ menyebabkan tanaman tumbuh terhambat sehingga ukuran tanaman menjadi relatif lebih kecil.

\section{KESIMPULAN DAN SARAN}

Dari semua parameter pertumbuhan dan hasil tanaman pakcoy, dosis kombinasi dolomit $4 \mathrm{t} \mathrm{ha}^{-1}+$ pupuk kandang ayam $30 \mathrm{t} \mathrm{ha}^{-1}$ berpengaruh terhadap peningkatan produktivitas rata-rata tertinggi dari semua perlakuan. Berdasarkan hasil penelitian dapat disarankan untuk penelitian selanjutnya, bisa meningkatkan dosis amelioran dolomit dengan pupuk kandang ayam untuk mengetahui puncak dari pengaruh pemberian amelioran terhadap pertumbuhan dan hasil tanaman pakcoy di lahan gambut.

\section{DAFTAR PUSTAKA}

Aryanti, E., Yulita, Y., \& Annisava, A. R. (2017). Pemberian Beberapa Amelioran Terhadap Perubahan Sifat Kimia Tanah Gambut. Jurnal Agroteknologi, 7(1), 19-26.

Atmaja, T., \& Damanik, M. M. B. (2017). Pengaruh 
Pemberian Pupuk Kandang Ayam, Pupuk Hijau, dan Kapur $\mathrm{CaCO} 3$ Pada Tanah Ultisol Terhadap Pertumbuhan Tanaman Jagung. Jurnal Online Agroekoteknologi, 5(1), 208-215.

Badan Pusat Statistik. (2018). Statistik Produksi Holtikultura Provinsi Kalimantan Tengah 2018. BPS: Kalimantan Tengah.

Kusuma, M. E. (2016). Efektifitas Pemberian Dosis Kotoran Ayam Terhadap Produksi Rumput Brachiaria Humidicola Pada Pemotongan Pertama Dan Kedua. Jurnal Ilmu Hewan Tropis, 5(1), 1-6.

Lubis, R. R., Hasibuan, S., \& Syafriadiman, S. (2017). Kelimpahan zooplankton pada kolam tanah gambut terhadap pemberian amelioran formulasi. Berkala Perikanan Terubuk, 45(1), 70-81.

Lubis, K. S., \& Hidayat, B. (2019). Ketersediaan Hara Fosfor Akibat Pemberian Biochar Sekam Padi dan Pupuk Kandang Sapi pada Inceptisol Kuala Bekala. Jurnal Pertanian Tropik, 6(2), 287-293.

Manurung, R. (2017). Pemetaan status unsur hara N, P dan $\mathrm{K}$ tanah pada perkebunan kelapa sawit di lahan gambut. Pedon Tropika, 3(1), 89-96.

Nazari, Y. A. (2020). Kondisi Status Hara Tanah Dan Jaringan Tanaman Kelapa Sawit (Elaeis guineensis jacq)
Yang Terdapat Di Kebun Kelapa Sawit Balai Pengawasan Dan Sertifikasi Benih Perkebunan Provinsi Kalimantan Selatan. Ziraa'ah Majalah Ilmiah Pertanian, 45(3), 274284.

Nurhayati, N. (2020). Pengaruh Pemberian Amandemen Pada Tanah Gambut Terhadap pH Tanah Gambut Dan Pertumbuhan Vegetatif Tanaman Kedelai. Wahana Inovasi: Jurnal Penelitian dan Pengabdian Masyarakat UISU, 9(1), 1-8.

Rahman, A., Subaedah, S., Muchdar, A., Ashar, J. R., \& Suriyanti, S. (2020). Pengaruh Pemberian Pupuk Kandang Ayam Terhadap Pertumbuhan Bayam Merah (Amaranthus Tricolor L.). Agrotekmas Jurnal Indonesia: Jurnal Ilmu Peranian, 1(1), 9-15.

Sari, Y. P., Haryadi, H., \& Arfianto, F. (2019). Pengaruh Pemberian Jenis Amelioran Terhadap Pertumbuhan Dan Produksi Bayam (Amaranthus tricolor L.) Pada Tanah Gambut. Daun: Jurnal Ilmiah Pertanian dan Kehutanan, 6(2), 160-171.

Wahyuningsih, A., Fajriani, S., \& Aini, N. (2017). Komposisi nutrisi dan media tanam terhadap pertumbuhan dan hasil tanaman pakcoy (brassica rapa I.) sistem hidroponik. Jurnal Produksi Tanaman, 4(8), 595-601 